\title{
Geochemistry and petrogenesis of Bandal basic rocks, Himachal Pradesh, NW Himalaya: implications for evolution of Proterozoic Lesser Himalayan basin
}

\author{
S. A. Rashid' and Kewal K. Sharma ${ }^{2}$ \\ 'Department of Geology, AMU, Aligarh - 202002, India \\ ${ }^{2}$ Wadia Institute of Himalayan Geology 33, Gen. Mahadeo Singh Road, Dehra Dun-248001, India
}

\begin{abstract}
The Proterozoic Bandal basic rocks, exposed in the Kulu-Rampur window, Lesser Himalaya, Himachal Pradesh, indicate two distinct (high-Ti and low-Ti) magma types. The majority of the basalts are characterised by high $\mathrm{TiO}_{2}(>2 \mathrm{wt} \%$ ), $\mathrm{Ti} / \mathrm{Y}$, $\mathrm{Ti} / \mathrm{Zr}, \mathrm{TiO}_{2} / \mathrm{K}_{2} \mathrm{O}$, and low $\mathrm{Rb} / \mathrm{Sr}$ ratios. They are enriched with high-field-strength (HFS) elements ( $\mathrm{Nb}, \mathrm{Zr}, \mathrm{Ti}$ ) relative to low-field-strength (LFS) incompatible elements $(\mathrm{K}, \mathrm{Rb})$. The low-Ti basalts are characterised by low $\mathrm{TiO}_{2}(<2 \mathrm{wt} \%), \mathrm{Ti} /$ $\mathrm{Y}$ and $\mathrm{Ti} / \mathrm{Zr}$, and high $\mathrm{Rb} / \mathrm{Sr}$ and $\mathrm{Rb} / \mathrm{Ba}$ ratios. The common factors of the Bandal basic rocks are their quartz-normative compositions and continental tholeiitic characteristics with $\mathrm{Nb} / \mathrm{La}$ always less than 1 . The compositional variations in the basalt types cannot simply be explained in terms of a declining extent of crustal contamination of an asthenosphere-derived melt with time, and instead it seems that the two magma types evolved from distinct parental magmas by various degrees of partial melting. Although some of the characteristics of the basalts (especially high-Ti rocks), like low Mg number $(\sim 30)$ and high concentrations of some of the LFS incompatible elements point towards assimilation and fractional crystallisation process, large variations in the incompatible element ratios like $\mathrm{Ti} / \mathrm{Y}, \mathrm{Ti} / \mathrm{Zr}, \mathrm{Rb} / \mathrm{Sr}$, and $\mathrm{Nb} / \mathrm{La}$ provide evidence for the derivation of these rocks through variable degrees of partial melting from an enriched mantle source.
\end{abstract}

Furthermore, the Bandal basic rocks, apart from field settings, are geochemically similar to other Proterozoic basic bodies like the Rampur volcanics, Mandi-Darla volcanics, Garhwal volcanics, and Bhimtal-Bhowlai volcanics of the Lesser Himalaya. This widespread Proterozoic continental tholeiitic magmatism over an area of $170,000 \mathrm{~km}^{2}$ in the Lesser Himalaya provides an evidence of plume activity in the region.

\section{INTRODUCTION}

Continental flood basalts (CFBs) are voluminous basalt provinces, which are the surface expressions of thermal anomalies in the mantle and are enriched with incompatible elements. Their petrogenetic studies have focused mainly on the role of mantle plumes and the contribution of the continental lithospheric mantle. Most of the studies indicate that CFB magmatism should be dominated by the melts derived from the sub-lithospheric mantle (White and McKenzie 1989; Arndt and Christensen 1992).

The earlier studies from the Lesser Himalaya (Bhat 1987; Ahmad and Tarney 1991; Bhat and Le Fort 1992) indicate that the basic rocks are of continental tholeiitic in nature with low $\mathrm{K}$ and Ti showing marked enrichment of the largeion lithophile elements (LILE) and light rare earth elements (LREE). With the addition of new data, Bhat et al. (1998) classified the mafic volcanism in the Rampur area (including Garhwal, Bhowali, Rampur, and Mandi volcanics) covering an area of $\sim 170,000 \mathrm{~km}^{2}$ as the Rampur flood basalt province.

In this paper, the petrogenesis and nature of the possible source for the generation of the Bandal basic rocks are discussed with a view to understand the palaeo-tectonics of the region and the contributions of the lithosphere/ asthenosphere in the evolution of these rocks. An attempt is also made to correlate the geochemical and field characteristics of the Bandal basic rocks with other widespread basic magmatic occurrences in the Lesser Himalayan region. Considering the aerial extent (over a strike length of $500 \mathrm{~km}$ ) of the basic magmatism in the Lesser Himalayan region and their typical CFB signatures, a 'plume' model of the late Palaeoproterozoic-Mesoproterozoic period is suggested for their origin.

\section{GEOLOGICAL SETTING}

The Bandal volcanics pertain to the Banjar Formation exposed in the Kulu-Rampur window, Himachal Pradesh, NW Lesser Himalaya (Fig. 1). Based on detailed mapping and lithological variations, Sharma (1977) has divided the Banjar Formation into the Manikaran Member, Green Bed Member, and the Bhallan Member. The Bhallan Member consists largely of phyllitic rocks "interbedded" with volcanics (Bhallan volcanics) and dark grey quartzites. The Green Bed Member, as the name indicates, is predominantly a mafic sequence with minor quartzite and phyllite 


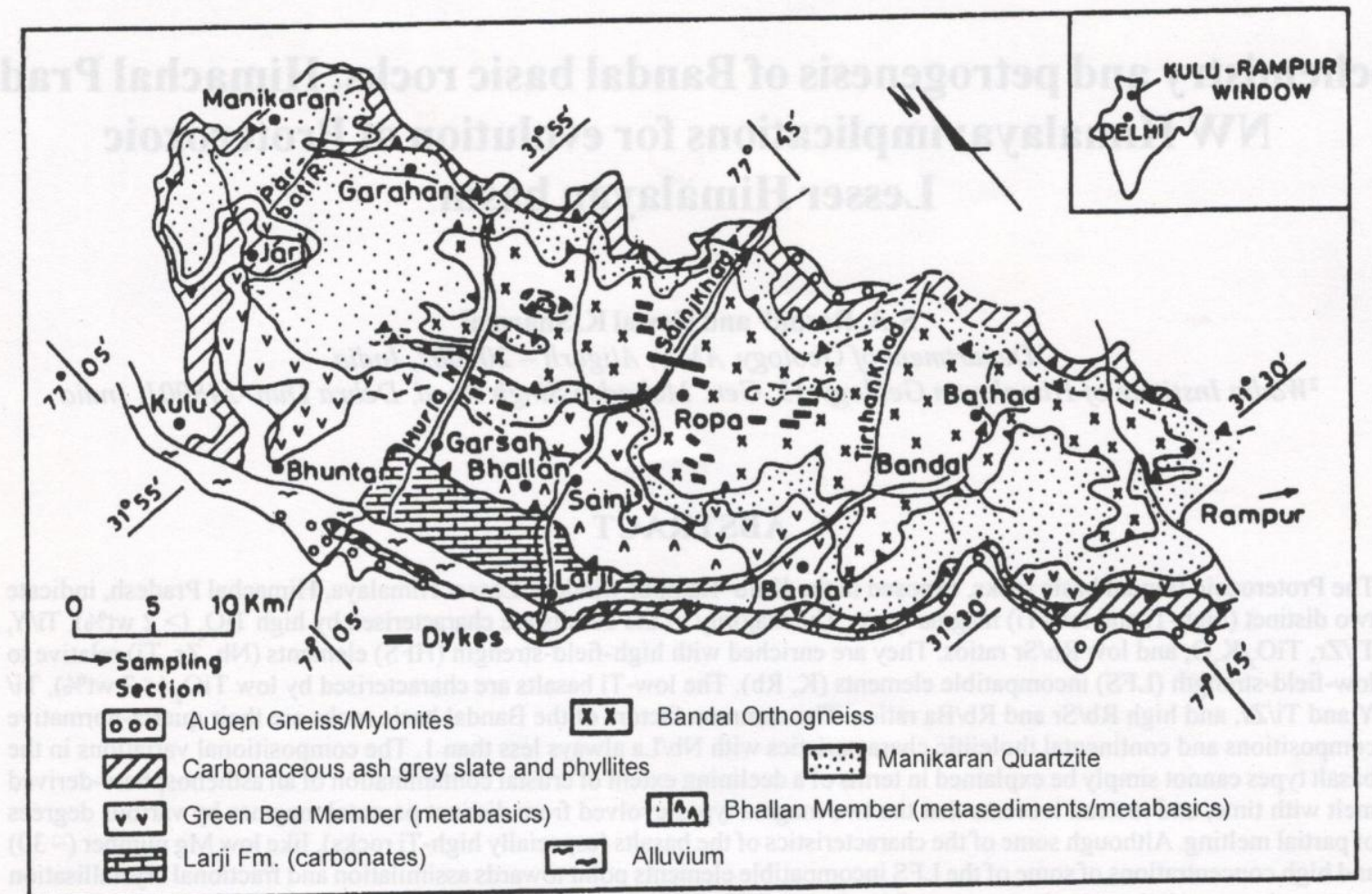

Fig. 1: Geological map of the Kulu-Rampur window showing the occurrence of the Bandal basic rocks (modified after Sharma 1977)

alternations. High-energy deposits with well-developed sedimentary structures are represented by pure white orthoquartzites of the Manikaran Member. The Bandal granite body occupies the core of the Kulu-Rampur window (Fig. 1). Samples were mainly collected from the dykes that occur in the Bandal granite (hereafter referred to as the Bandal dykes) and from the volcanics that are associated with the Bhallan Member (hereafter referred to as the Bhallan volcanics). The Bandal dykes and Bhallan volcanics are collectively called the Bandal basic rocks. The Bandal dykes intrude the Bandal granite and occur stratigraphically at lower positions whereas the Bhallan volcanics occur at stratigraphically higher positions and the age gap between the two sequences may be small. In the absence of isotopic age data for the Bandal basics and their presence as dykes in the Palaeoproterozoic Bandal granite (1904+70 Ma; Frank et al. 1977), we consider them as the representatives of the Late Palaeoproterozoic-Mesoproterozoic basic magmatism in the area. However, this needs to be better constrained with isotopic data.

The Bhallan volcanics are fine- to medium-grained amphibolitic rocks and occur as flows in fine-grained clastic sedimentary rocks. Their interflow thickness varies from 3 to $5 \mathrm{~m}$ whereas the thickness of dykes goes up to $20 \mathrm{~m}$. The relatively thinner flows are aphanitic, whereas the thicker ones show the grain size variation from margins to central parts. The flows are vesicular and amygdaloidal in nature, and the amygdales are generally filled up by quartz, epidote, and minor amounts of calcite.

\section{PETROGRAPHY}

The Bhallan volcanics are fine- to medium-grained foliated rocks. Primary clinopyroxene and plagioclase occur both as phenocrysts and in the groundmass. Though alteration of clinopyroxenes is uncommon, albitisation of plagioclase is noticed in the volcanic samples. Fractures are filled up by quartz and epidote. Augite is the dominant pyroxene whereas plagioclase ranges in composition from andesine to labradorite. Secondary minerals include epidote, quartz, and chlorite. Fe-Ti oxides occur in minor amounts.

The dyke samples are less altered and exhibit the conspicuous ophitic texture. The anorthite content varies from the contact to central part of the dyke. At many places, twin lamellae are bent and fractured under the stress during or after the intrusion. But, such deformed crystals are either absent or present in a very small number in the central part of the dyke. Diopside present in a subordinate amount shows good prismatic cleavage. Calcite occurs as subhedral crystals and at places it is seen replaced by quartz. The textural features of epidotes indicate their secondary nature. Most probably, they were formed by the breakdown of amphiboles 
during the late stage hydrothermal alteration. Opaques, chlorite, and leucoxene form minor accessory minerals, whereas apatite is rarely noticed.

\section{ANALYTICAL NOTES}

After a careful examination of the rock samples under microscope, thirty representative samples were selected for chemical analysis. Some of the major oxides $\left(\mathrm{SiO}_{2}, \mathrm{Al}_{2} \mathrm{O}_{3}\right.$, $\left.\mathrm{MgO}, \mathrm{Fe}_{2} \mathrm{O}_{3}{ }^{ }, \mathrm{CaO}\right)$ and trace elements ( $\mathrm{Rb}, \mathrm{Sr}, \mathrm{Ga}, \mathrm{Zr}$ ) were determined using SIEMENS SRS 3000 sequential X-ray fluorescence Spectrometer (XRF) at the Wadia Institute of Himalayan Geology, Dehra Dun. The glass-bead technique was used for the major elements and pressed powder pelletes for the trace elements. Before analysis, rock powders were ignited at $950-1000{ }^{\circ} \mathrm{C}$ in an oven to estimate the loss on ignition (LOI) or to determine the approximate volatile content of the rock.

Some of the major oxides $\left(\mathrm{TiO}_{2}, \mathrm{MnO}, \mathrm{P}_{2} \mathrm{O}_{5}\right)$ and trace elements $(\mathrm{Nb}, \mathrm{Y}, \mathrm{Sc}, \mathrm{Ba}, \mathrm{V})$ together with rare earth elements (La, Ce, Nd, Sm, Eu, Gd, Dy, Er, Yb, Lu) were analysed using Inductively-Coupled Plasma Atomic Emission Spectrometer (ICP-AES), whereas $\mathrm{Na}_{2} \mathrm{O}$ and $\mathrm{K}_{2} \mathrm{O}$ were determined by Atomic Absorption Spectrometer (AAS) at the Wadia Institute of Himalayan Geology, Dehra Dun. The analytical uncertainty was less than $\pm 2 \%$ for $\mathrm{TiO}_{2}, \mathrm{MnO}, \mathrm{Na}_{2} \mathrm{O}, \mathrm{Y}$, and $\mathrm{Ba}$; less than $\pm 4 \%$ for $\mathrm{P}_{2} \mathrm{O}_{5}$ and $\mathrm{K}_{2} \mathrm{O}$; and less than $\pm 10 \%$ for $\mathrm{Nb}, \mathrm{Sc}, \mathrm{V}$. The precision for all the rare earth elements (REE) analysed was greater than $95 \%$, and the precision was greater than $90 \%$ ( $95 \%)$ for Lu. Rathi et al. (1996) have given further analysis details.

\section{GEOCHEMISTRY}

The major element concentrations of the Bandal basic rocks are presented in Table 1. In general, all the major oxide contents represent a more evolved subalkaline tholeiites to slightly alkaline basaltic characteristics according to the total alkali - silica classification (Le Bas et al. 1986). Most of the analysed samples exhibit quartz-normative compositions and some have olivine-normative compositions. Two samples, however, have silica undersaturated nepheline-normative compositions showing alkali affinity with high $\mathrm{K}_{2} \mathrm{O}$ contents. The silica content ranges from 47 to $53 \mathrm{wt} \%$. The dyke samples show a narrow range (49-51 wt\%) of silica content, whereas the Bhallan volcanics show a relatively wide range (47-53 wt \%) of $\mathrm{SiO}_{2}$ content. The high silica content of the volcanic rocks may be attributed to crustal contamination or differentiation of the parent magma. The role of these processes (contamination and differentiation) in any magmatic suite can be constrained by using immobile trace element chemistry. $\mathrm{Zr}$ is considered one of the most immobile elements during low-grade alteration of basaltic rocks and is essentially incompatible with basaltic systems (Tarney et al. 1979). Accordingly, instead of $\mathrm{Mg}$ number, $\mathrm{Zr}$ abundances are used as a measure of magma differentiation for the Bandal basic rocks. A good negative correlation between $\mathrm{Zr}$ and $\mathrm{MgO}$ is exhibited in variation diagrams (Fig. 2). It is difficult to differentiate between dyke and volcanic samples in the variation diagrams although most of the volcanics have relatively high concentrations of $\mathrm{MgO}(10 \mathrm{wt} \%)$ and slightly lower $\mathrm{Fe}_{2} \mathrm{O}_{3}{ }^{1}(14 \mathrm{wt} \%)$. The high concentrations of $\mathrm{Na}$ in dykes and volcanic rocks might have been due to metamorphism, resulting in the albitisation or spilitisation of the rocks, and this may be one of the reasons why two of the samples exhibit the nepheline-normative compositions.

Twelve selected samples were analysed for REE and the data are listed in Table 1. The chondrite-normalised patterns are shown in Fig. 3. All the samples show rare earth element enrichment from about 103-141 x chondrite for LREE and about 9-14 x chondrite for heavy rare earth elements (HREE) in the dyke samples and $74-127 \times$ chondrite and 6-10 $x$ chondrite for LREE and HREE, respectively, in the Bhallan volcanics. Moderate to low negative Eu anomalies $\left(\mathrm{Eu} / \mathrm{Eu}^{*}=0.72-0.96\right)$ are observed in both the dyke and volcanic samples. On the basis of geochemistry, two distinct groups are recognised in the Bhallan volcanic samples. The first group (MJ-136, MJ-137, MJ-138) is characterised by

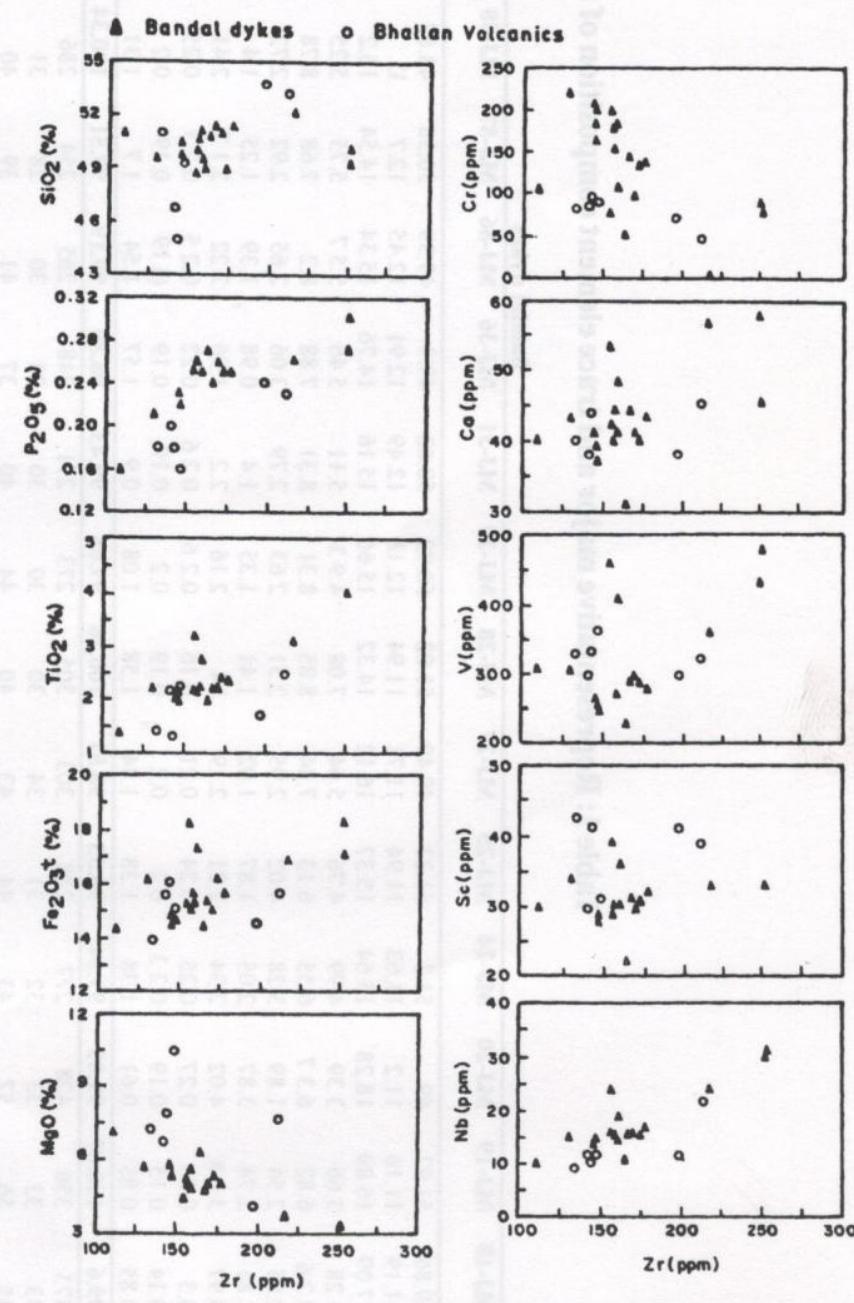

Fig. 2: Variation diagrams for the Bandal basic rocks showing some important major and trace elements against $\mathrm{Zr}$ 


\section{S. A. Rashid and Kewal K. Sharma}

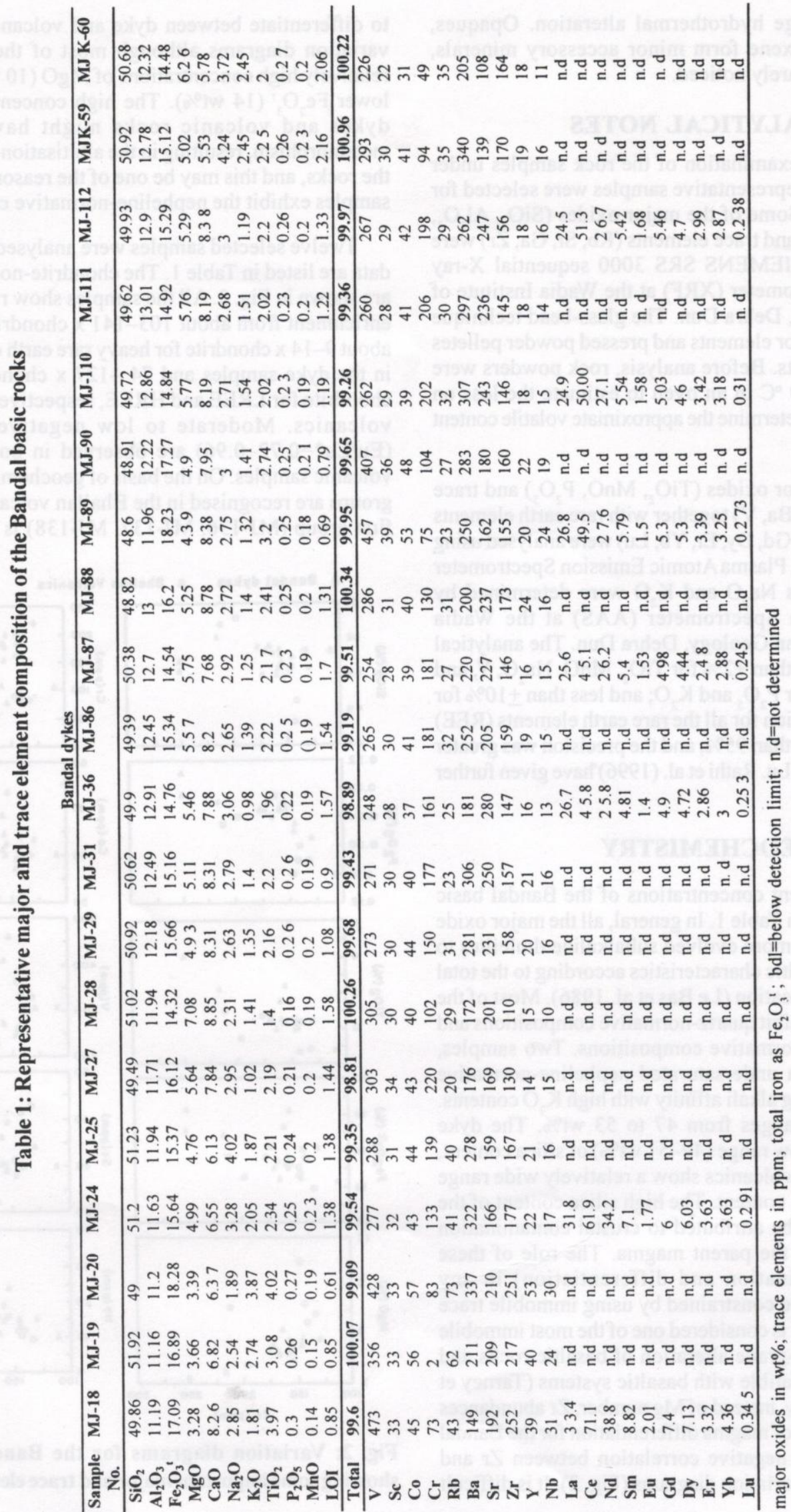


Table 1 (contd.)

\begin{tabular}{|c|c|c|c|c|c|c|}
\hline Sample $\mathrm{No}$ & MJ-136 & MJ-137 & & & & \\
\hline & & & & MJ-141 & MJ-143 & MJ-144 \\
\hline $\mathrm{SiO}_{2}$ & 53.52 & 51.01 & 44.82 & 52.92 & 46.64 & 49.09 \\
\hline $\mathrm{Al}_{2} \mathrm{O}_{3}$ & 12.55 & 12.05 & 11.76 & 12.15 & 12.22 & 11.44 \\
\hline $\mathrm{Fe}_{2} \mathrm{O}_{3}{ }^{\mathrm{t}}$ & 14.55 & 13.96 & 16.13 & 15.72 & 15.64 & 15.13 \\
\hline MgO & 4.1 & 7.23 & 7.91 & 7.66 & 6.72 & 10.5 \\
\hline $\mathrm{CaO}$ & 5.67 & 6.79 & 7.62 & 2.59 & 5.88 & 2.62 \\
\hline $\mathrm{Na}_{2} \mathrm{O}$ & 3.45 & 3.37 & 2.64 & 2.65 & 4.37 & 2.76 \\
\hline $\mathrm{K}_{2} \mathrm{O}$ & 2.72 & 2.11 & 1.84 & 0.24 & 1.07 & 3.05 \\
\hline $\mathrm{TiO}_{2}$ & 1.73 & 1.42 & 1.32 & 2.49 & 2.17 & 2.27 \\
\hline $\mathbf{P}_{2} \mathbf{O}_{5}$ & 0.24 & 0.18 & 0.18 & 0.23 & 0.2 & 0.16 \\
\hline MnO & 0.24 & 0.23 & 0.24 & 0.21 & 0.21 & 0.18 \\
\hline LOI & 0.94 & 1.4 & 1.95 & 4.47 & 2.15 & 3.63 \\
\hline Total & 99.71 & 99.75 & 96.41 & 101.33 & 97.27 & 100.83 \\
\hline $\bar{V}$ & 295 & 329 & 334 & 322 & 298 & 363 \\
\hline Sc & 41 & 43 & 42 & 39 & 30 & 31 \\
\hline Co & 38 & 40 & 44 & 45 & 38 & 39 \\
\hline $\mathrm{Cr}$ & 67 & 79 & 95 & 42 & 83 & 88 \\
\hline $\mathbf{R b}$ & 40 & 24 & 23 & 22 & 26 & 41 \\
\hline Ba & 515 & 314 & 277 & 35 & 183 & 240 \\
\hline $\mathrm{Sr}$ & 107 & 97 & 81 & bdl & 81 & 12 \\
\hline $\mathbf{Z r}$ & 197 & 133 & 143 & 212 & 141 & 147 \\
\hline $\mathbf{Y}$ & 27 & 19 & 20 & 14 & 12 & 12 \\
\hline $\mathbf{N b}$ & 12 & 9 & 10 & 22 & 12 & 12 \\
\hline La & 30 & 20.1 & 20 & n.d & 24.3 & 17.6 \\
\hline $\mathrm{Ce}$ & 66.3 & 42.4 & 45.2 & n.d & 47.9 & 42.4 \\
\hline 61 & 36 & 23.8 & 23.2 & n.d & 23.7 & 26.5 \\
\hline Sm & 6.61 & 4.79 & 4.66 & n.d & 5.44 & 5.43 \\
\hline Lu & 1.5 & 1.24 & 1.24 & n.d & 1.4 & 1.61 \\
\hline Gd & 6.1 & 4.53 & 4.69 & n.d & 4.61 & 4.87 \\
\hline Dy & 6.05 & 4.67 & 4.83 & n.d & 4.49 & 4.32 \\
\hline $\mathbf{E r}$ & 2.87 & 2.82 & 2.75 & n.d & 2.5 & 2.68 \\
\hline $\mathbf{Y b}$ & 3.84 & 3.13 & 3.36 & n.d & 2.38 & 2.6 \\
\hline$\underline{\text { Lu }}$ & 0.254 & 0.237 & 0.248 & n.d & 0.143 & 0.174 \\
\hline
\end{tabular}
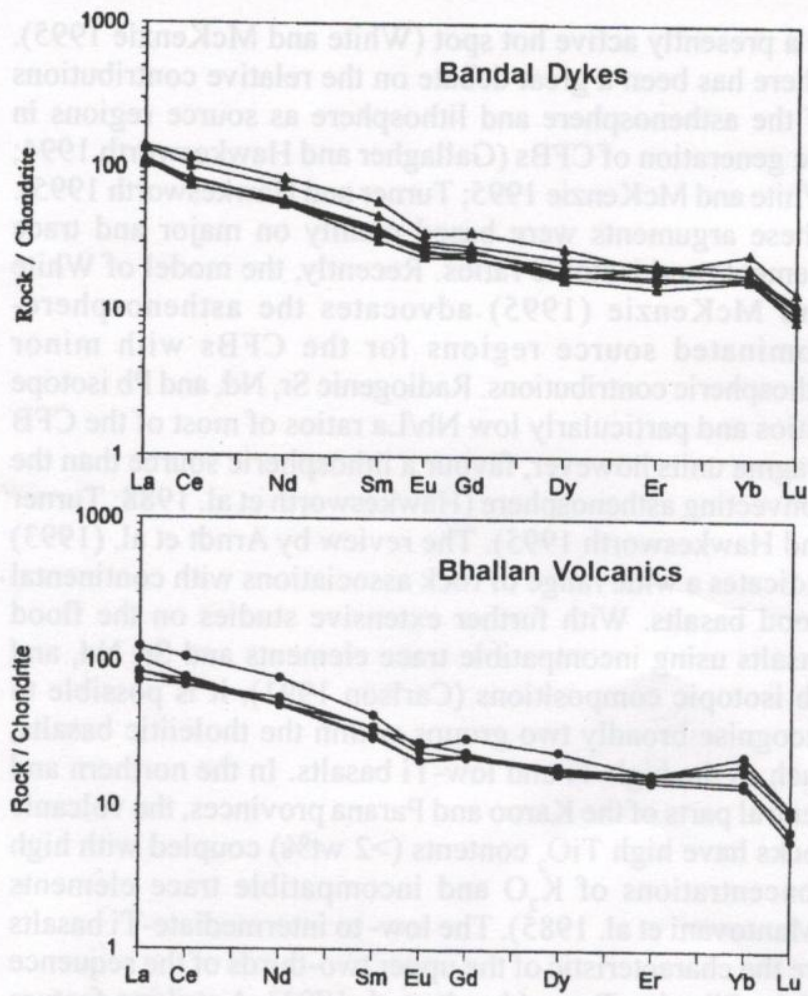

Fig. 3: Chondrite-normalised REE patterns. Normalising values after Sun and McDonough (1989) low- $\mathrm{Ti}\left(\mathrm{TiO}_{2}<2 \%\right), \mathrm{Ti} / \mathrm{Y}<500, \mathrm{Zr} / \mathrm{Nb}>14$, and $\mathrm{Gd}_{\mathrm{N}} / \mathrm{Yb}_{\mathrm{N}}<1.4$ whereas the other group (MJ-141, MJ-143, MJ-144) has the characteristics more or less similar to the dykes having high$\mathrm{Ti}\left(\mathrm{TiO}_{2}>2 \%\right), \mathrm{Ti} / \mathrm{Y}>500, \mathrm{Zr} / \mathrm{Nb}<13$, and $\mathrm{Gd} / \mathrm{Yb}_{\mathrm{N}}>1.5$ (see Table 1). Thus, broadly, the Bandal basic rocks are divisible into low-Ti and high-Ti basalts. This division into high- and low-Ti magmas can be recognised in all the Mesozoic CFBs of Gondwana, Karoo, Ferrar, and Parana provinces (Duncan et al. 1984; Cox 1978; Hergt et al. 1991; Garland et al. 1996). Certain additional chemical features also allow discrimination between the high- and low-Ti groups. Notably, the high-Ti basalts are relatively enriched with LILE.

\section{MAGMA TYPE}

The multi-element spidergrams provide useful means for comparing basalts of different tectonic settings. Since spidergrams include LILE, HFS elements and REE, the relative enrichment and depletion of the elements can provide valuable information on the petrogenetic process or source characteristics of any suite. The Bandal basic rocks fall within the plate basalt (WPB) tectonic setting when plotted on the spidergram against the normalised mid-ocean ridge basalts (MORB). Fig. 4 illustrates a good comparison between the chemical patterns of the Bandal basic rocks and within-plate tholeiitic basalts. From this plot, it is evident that the most incompatible elements ( $\mathrm{Ba}$ and $\mathrm{Nb}$ ) are more enriched 


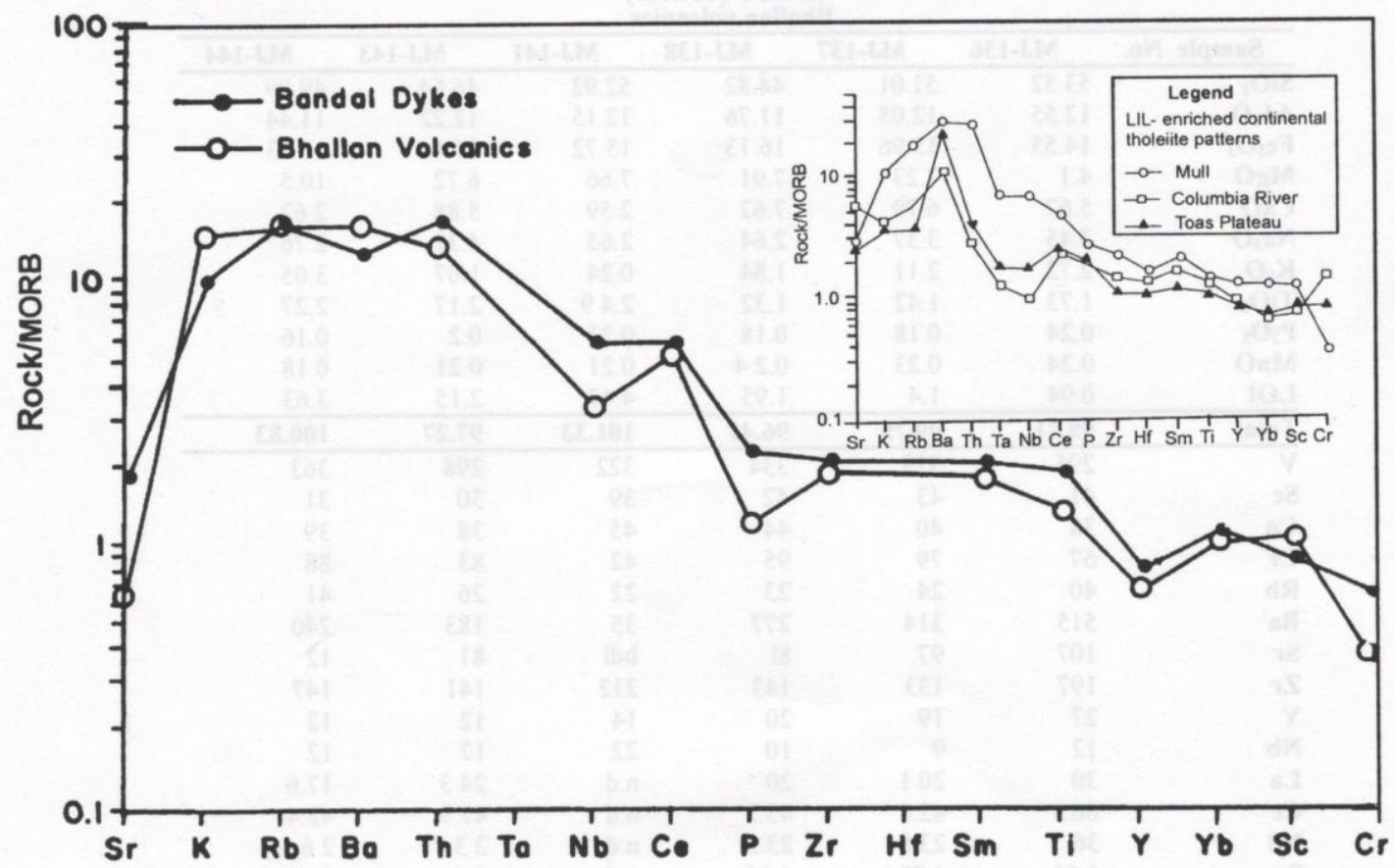

Fig. 4: MORB-normalised trace element patterns for the Bandal basic rocks. Typical LILE enriched within-plate basalt patterns (inset) after Pharaoh and Pearce (1984) are also shown for comparison. Normalising values after Pearce (1982)

whereas $\mathrm{Y}$ and $\mathrm{Yb}$ (compatible with garnet) and $\mathrm{Sc}$ and $\mathrm{Cr}$ (compatible with all mafic phases) show little change relative to the tholeiitic MORB. Pearce (1982) argues that most of the elements, except $\mathrm{Sr}$ (compatible with plagioclase), and $\mathrm{Sc}$ and $\mathrm{Cr}$ (compatible with mafic phases), have low bulk distribution coefficients between the basalt magma and a crystallising assemblage containing olivine, plagioclase, and clinopyroxene. Therefore, as the fractional crystallisation proceeds the magma gets enriched with incompatible elements. This observation implies that the multi-element spidergram of the Bandal rocks with an enriched incompatible element pattern indicate the involvement of fractional crystallisation process in the generation of these basic rocks. However, as noted above, the fractional crystallisation does not significantly change ratios of elements with similar degrees of incompatibility (e.g. La/Nb, $\mathrm{Zr} / \mathrm{Y}$ ).

\section{PETROGENESIS AND DISCUSSION}

The continental tholeiitic rocks are considered the principal magmatic rocks generated in rift environments by mantle plume (?) that gave rise to the CFB provinces. The melting in the plume head yields flood basalts whereas the melting in the tail is thought to produce the volcanic rocks of oceanic islands (Duncan 1978; White and McKenzie 1989; Campbell and Griffiths 1990). The importance of plumes in CFBs has long been noted, and most provinces can be traced to a presently active hot spot (White and McKenzie 1995). There has been a great debate on the relative contributions of the asthenosphere and lithosphere as source regions in the generation of CFBs (Gallagher and Hawkesworth 1994; White and McKenzie 1995; Turner and Hawkesworth 1995). These arguments were based mainly on major and trace elements and isotopic ratios. Recently, the model of White and McKenzie (1995) advocates the asthenospheredominated source regions for the CFBs with minor lithospheric contributions. Radiogenic $\mathrm{Sr}, \mathrm{Nd}$, and $\mathrm{Pb}$ isotope ratios and particularly low $\mathrm{Nb} / \mathrm{La}$ ratios of most of the $\mathrm{CFB}$ magma units however, favour a lithospheric source than the convecting asthenosphere (Hawkesworth et al. 1988; Turner and Hawkesworth 1995). The review by Arndt et al. (1993) indicates a wide range of rock associations with continental flood basalts. With further extensive studies on the flood basalts using incompatible trace elements and $\mathrm{Sr}, \mathrm{Nd}$, and $\mathrm{Pb}$ isotopic compositions (Carlson 1991), it is possible to recognise broadly two groups within the tholeiitic basalts, such as the high-Ti and low-Ti basalts. In the northern and central parts of the Karoo and Parana provinces, the volcanic rocks have high $\mathrm{TiO}_{2}$ contents $(>2$ wt $\%)$ coupled with high concentrations of $\mathrm{K}_{2} \mathrm{O}$ and incompatible trace elements (Mantovani et al. 1985). The low- to intermediate-Ti basalts are the characteristic of the upper two-thirds of the sequence of the Siberian Traps (Arndt et al. 1993). A striking feature of the flood basalts is the negative $\mathrm{Nb}-\mathrm{Ta}$ anomalies with the exception of Deccan that has small to negligible 


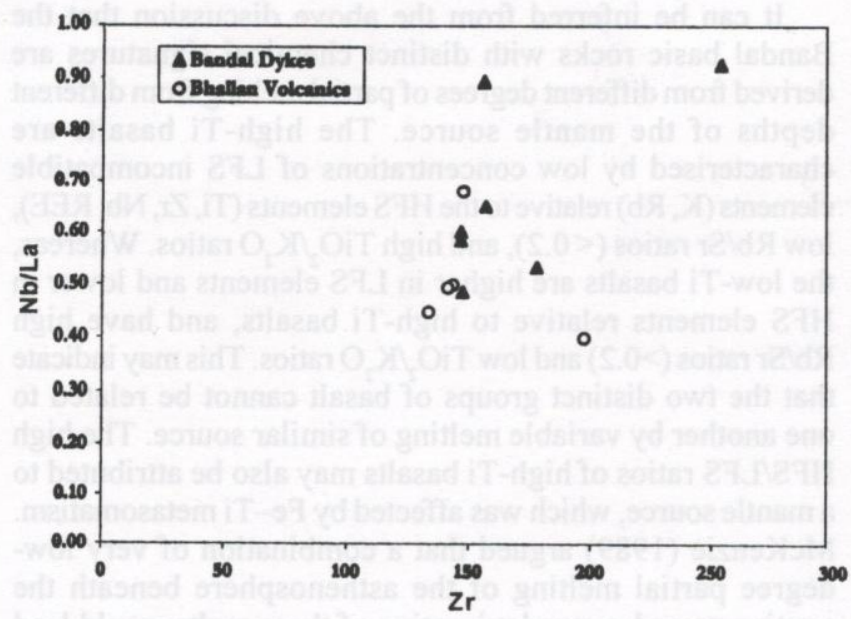

Fig. 5: $\mathrm{Zr}$ versus $\mathrm{Nb} / \mathrm{La}$ plot for the Bandal basic rocks. Note the near-constant $\mathrm{Zr}$ concentrations for a range of $\mathrm{Nb} / \mathrm{La}$ values.

$\mathrm{Nb}-\mathrm{Ta}$ anomalies (Mahoney et al. 1982; Lightfoot and Hawkesworth 1988).

The present study reveals high-Ti continental tholeiitic signature of the Bandal basic rocks with the exception of a few samples depicting their alkaline affinity. Otherwise, most of the samples are characterised by high concentrations of incompatible elements, high-field-strength (HFS) elements relative to low-field-strength (LFS) incompatible elements, and enriched LREE patterns. Depletion of $\mathrm{Nb}$ concentrations in the rocks may be attributed to a residual titanite mineral in the source region (Clague and Frey 1982) or contamination of the magmas by Nb-poor continental crust, or fusion of low-melting point veins in the lithospheric mantle that have low $\mathrm{Nb} / \mathrm{LILE}$ ratios.

In order to know the exact process of enrichment of the samples (i.e. assimilation and fractional crystallisation versus enriched source), incompatible trace element plots were used (Fig. 5). A rapid increase in $\mathrm{Zr}$ concentration is generally predicted with little or no change in incompatible trace element ratios for the assimilation and fractional crystallisation (AFC) model (Rajamani et al. 1989; Vetter and Shervais 1992). From Fig. 5, it is also clear that the flows represent two distinct groups. The low-Ti group is characterised by low $\mathrm{Zr}$ and $\mathrm{Nb} / \mathrm{La}$ (HFS elements/LFS elements) values in contrast to high-Ti (including dykes and volcanic) samples, which have relatively high but nearly constant $\mathrm{Zr}$ (145-155 ppm) values and a large variation in $\mathrm{Nb} / \mathrm{La}$ values from 0.5 to 0.9 . The wide range of these ratios $(\mathrm{Nb} / \mathrm{La}, \mathrm{Rb} / \mathrm{Nb}$, and $\mathrm{Rb} / \mathrm{La})$ precludes any $\mathrm{AFC}$ processes for the high-Ti rocks. However, some of the samples with high $\mathrm{Zr}$ concentrations ( $>170 \mathrm{ppm})$, incompatible element concentrations (especially $\mathrm{Ba}$ ), and lower $\mathrm{Mg}$ number (as low as 26) invoke the involvement of AFC process during the evolution of these rocks. Furthermore, the important characteristics, like low $\mathrm{Sr}$ as well as negative $\mathrm{Eu}$ anomalies of the high-Ti basalts, suggest

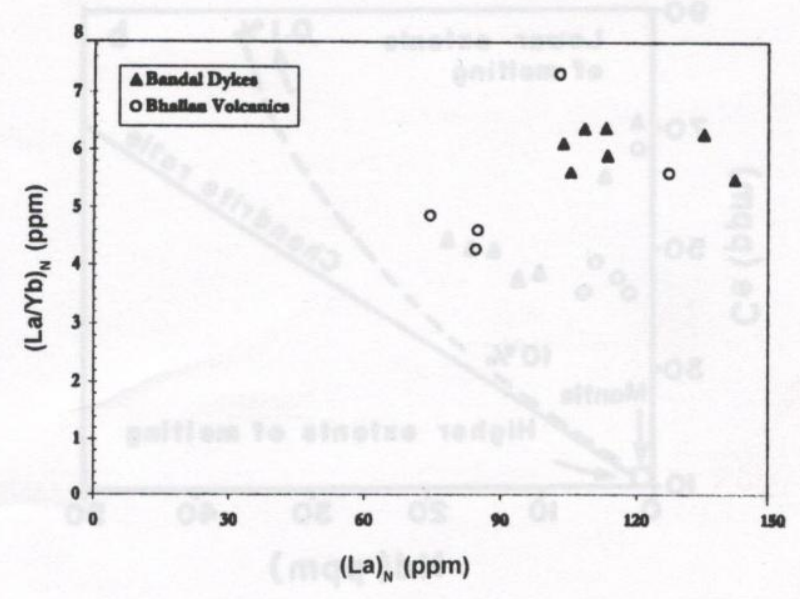

Fig. 6: $(\mathrm{La} / \mathrm{Yb})_{\mathrm{N}}$ versus $(\mathrm{La})_{\mathrm{N}}$ for the Bandal basic rocks

that fractional crystallisation involving plagioclase has played a role in the generation of these rocks. However, a large variation in incompatible element ratios (e.g., La/Yb, $\mathrm{Zr} / \mathrm{Y}, \mathrm{Ti} / \mathrm{Y}, \mathrm{Zr} / \mathrm{Nb}, \mathrm{Nb} / \mathrm{La}$, and $\mathrm{Rb} / \mathrm{Nb}$ ) in the rocks cannot be explained by crystal fractionation alone. These variations probably represent different degrees of partial melting from a common source and reflect the enriched mantle source characteristics.

The samples plotted on the $(\mathrm{La} / \mathrm{Yb})_{\mathrm{N}}$ versus $(\mathrm{La})_{N}$ diagrams further indicate the two distinct groups of rock and also support the inference that these rocks evolved by different degrees of partial melting of a mantle source. In general, on this type of plot, a linear relationship will be defined by the samples if they are derived by different degrees of partial melting of a common source; however, the plots may shift horizontally to higher $\mathrm{X}$-axis values because of crystal fractionation (Feigenson et al. 1983; Rossy et al. 1992; Bradshaw et al. 1993). A broad positive linear pattern is exhibited by the Bandal basic rocks in the diagram (Fig. 6), indicating that they were formed by different degrees of melting of a source with similar $(\mathrm{La} / \mathrm{Yb})_{\mathrm{N}}$. A lower degree of melting resulted the samples with higher $(\mathrm{La})_{\mathrm{N}}$ and $(\mathrm{La} / \mathrm{Yb})_{\mathrm{N}}$ whereas samples with lower $(\mathrm{La})_{N}$ and $(\mathrm{La} / \mathrm{Yb})_{N}$ were formed by a higher degree of melting. Furthermore, the shifting of the high-Ti basalts to higher $\mathrm{X}$-axis values suggests the involvement of crystal fractionation in producing these rocks.

On the Ce-Nd bivariate plot (Fig. 7), the samples lie above the chondrite ratio line. This may indicate the melting conditions of the basalts where the samples with lower Ce and $\mathrm{Nd}$ contents appear to have been formed by higher extents of melting than the samples with higher contents. Because $\mathrm{Ce}$ is relatively incompatible with common upper mantle phases, its abundances in magmas are inversely proportional to the extent of melting. This inference is further 


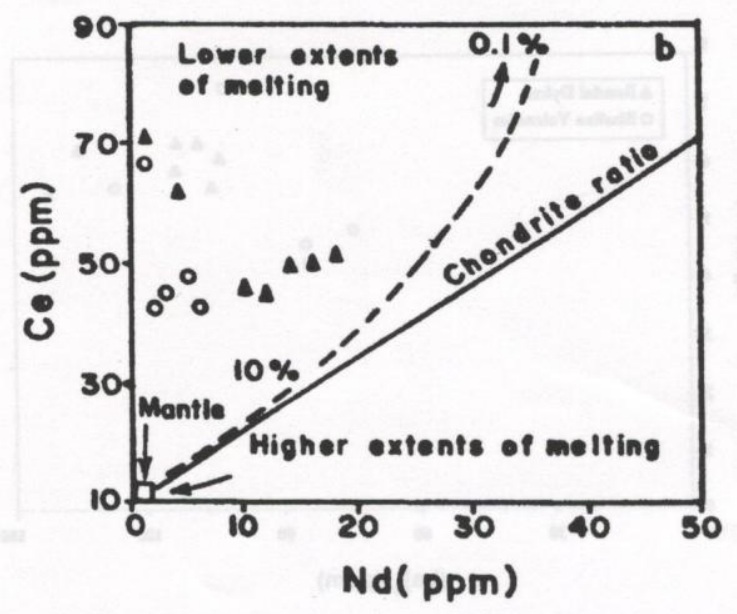

Fig. 7: Ce versus Nd variations in the Bandal basic rocks

substantiated by $\mathrm{Nb} / \mathrm{Y}-\mathrm{Ti} / \mathrm{Y}$ diagram of Pearce (1982) where the Bandal basalts depict their enriched character and plot along the within-plate vector (Fig. 8). From Fig. 8, it can also be concluded that, having low $\mathrm{Nb} / \mathrm{Y}$ and $\mathrm{Ti} / \mathrm{Y}$ values, the low-Ti flows are plotted separately from the other flows, whereas the dyke samples are characterised by high $\mathrm{Nb} / \mathrm{Y}$ and $\mathrm{Ti} / \mathrm{Y}$ ratios.
It can be inferred from the above discussion that the Bandal basic rocks with distinct chemical signatures are derived from different degrees of partial melting from different depths of the mantle source. The high-Ti basalts are characterised by low concentrations of LFS incompatible elements $(\mathrm{K}, \mathrm{Rb})$ relative to the HFS elements $(\mathrm{Ti}, \mathrm{Zr}, \mathrm{Nb}, \mathrm{REE})$, low $\mathrm{Rb} / \mathrm{Sr}$ ratios $(<0.2)$, and high $\mathrm{TiO}_{2} / \mathrm{K}_{2} \mathrm{O}$ ratios. Whereas, the low-Ti basalts are higher in LFS elements and lower in HFS elements relative to high-Ti basalts, and have high $\mathrm{Rb} / \mathrm{Sr}$ ratios $(>0.2)$ and low $\mathrm{TiO}_{2} / \mathrm{K}_{2} \mathrm{O}$ ratios. This may indicate that the two distinct groups of basalt cannot be related to one another by variable melting of similar source. The high HFS/LFS ratios of high-Ti basalts may also be attributed to a mantle source, which was affected by Fe-Ti metasomatism. McKenzie (1989) argued that a combination of very lowdegree partial melting of the asthenosphere beneath the continents and upward migration of these melts would lead to metasomatism of the material constituting the base of the continental lithosphere that is strongly enriched with incompatible elements. Experimental studies (O'Hara 1968; Takahashi and Kushiro 1983; Ellam and Cox 1989) indicate that melts formed at depths between 80 and $100 \mathrm{~km}$ beneath the continental lithosphere at pressures between 25 and 35 $\mathrm{kbar}$ are rich in $\mathrm{MgO}$ and $\mathrm{FeO}$, and if the degree of melting is relatively low (5-13\%) and the plume source geochemically enriched, they will have elevated

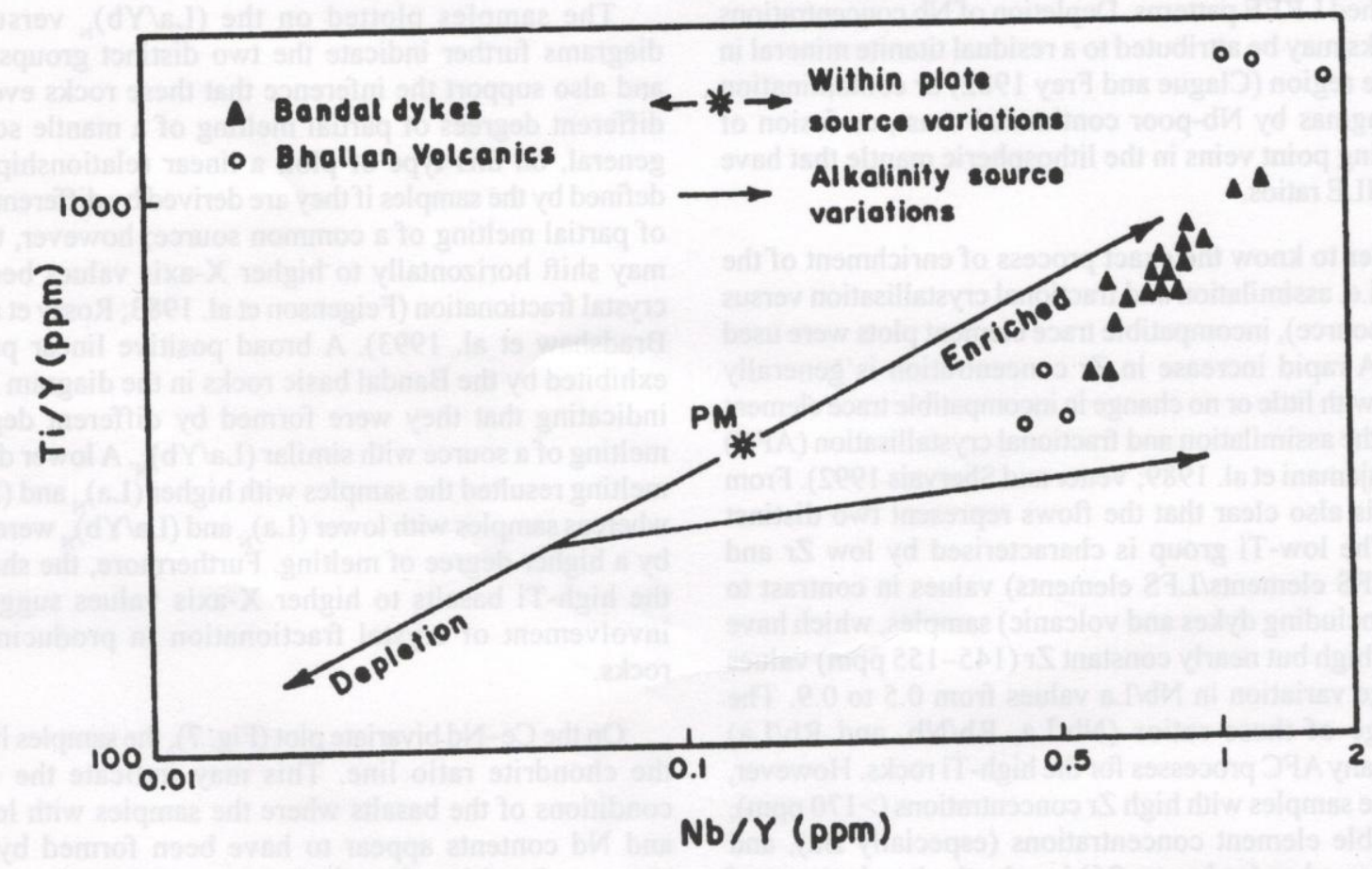

Fig. 8: Ti/Y and Nb/Y discrimination diagram (Pearce 1982) for the Bandal basic rocks. Petrogenetic pathways for within-plate and alkaline basalts are shown. Note the enriched source character of the Bandal basic rocks. 
concentrations of incompatible elements. Relatively enriched $\mathrm{MgO}, \mathrm{FeO}$, and incompatible elements of high-Ti basalts thus suggest their origin by a small degree of melting of an enriched source. The characteristics like high $\mathrm{TiO}_{2} / \mathrm{K}_{2} \mathrm{O}, \mathrm{Nb} /$ $\mathrm{Rb}$, and $\mathrm{La} / \mathrm{Rb}$ ratios of high-Ti basalts are consistent with the melts produced by small degrees of partial melting of the asthenosphere (e.g., Hawkesworth et al. 1984). Therefore, it can be said that the high-Ti signatures of the majority of basalts resulted from small-degree asthenospheric melts, which were enriched with incompatible elements such as $\mathrm{Ti}$, and could either be derived directly from the asthenosphere (via plume melts), or through enrichment of the lithospheric mantle by such small-degree melts, from which the high-Ti signatures can be inherited during subsequent melting.

The low-Ti basalts with low Ti/Y $(<500)$ and $\mathrm{Nb} / \mathrm{La}(<1)$ ratios are inferred to be the products of the depleted lithospheric melts. The relatively low $\mathrm{Fe}_{2} \mathrm{O}_{3}{ }^{\mathrm{t}}$ is consistent with a source also depleted in some major elements, but because it is associated with relatively high $\mathrm{SiO}_{2}$, it may be in part due to melting under hydrous conditions (Jaques and Green 1980). And low $\mathrm{TiO}_{2}, \mathrm{Na}_{2} \mathrm{O}$, and $\mathrm{P}_{2} \mathrm{O}_{5}$ contents can also be due to either a large degree of melting of fertile source regions, or smaller degrees of melting of a more depleted source (Falloon and Green 1988).

\section{REGIONAL IMPLICATIONS OF BASIC MAGMATISM IN THE LESSER HIMALAYA}

The widespread Proterozoic tholeiitic basalt magmatism over a strike-length of $500 \mathrm{~km}$ in the Lesser Himalaya is evident from the present work and the studies of Bhat and Le Fort (1992) from the Rampur area, Ahmad and Bhat (1987) from the Mandi-Darla area, Ahmad and Tarney (1991) from the Rudraprayag area and Bhat and Ahmad (1987) from the Bhimtal-Bhowali area (Fig. 9). In the Rampur area, the tholeiites are "interbedded" with orthoquartzite unit, which is the extension of the Manikaran Quartzites of the present study area (i.e. Bandal). The Mandi-Darla volcanics occur as flows "interbedded" with low-grade metasedimentary rocks (Sundernagar Formation), which are similar in lithology to the Bhallan Member of the present study area. Similar association of basic rocks with quartzites and phyllites is also known from Garhwal and the Bhimtal-Bhowali areas. Apart from their typical field associations, their geochemical

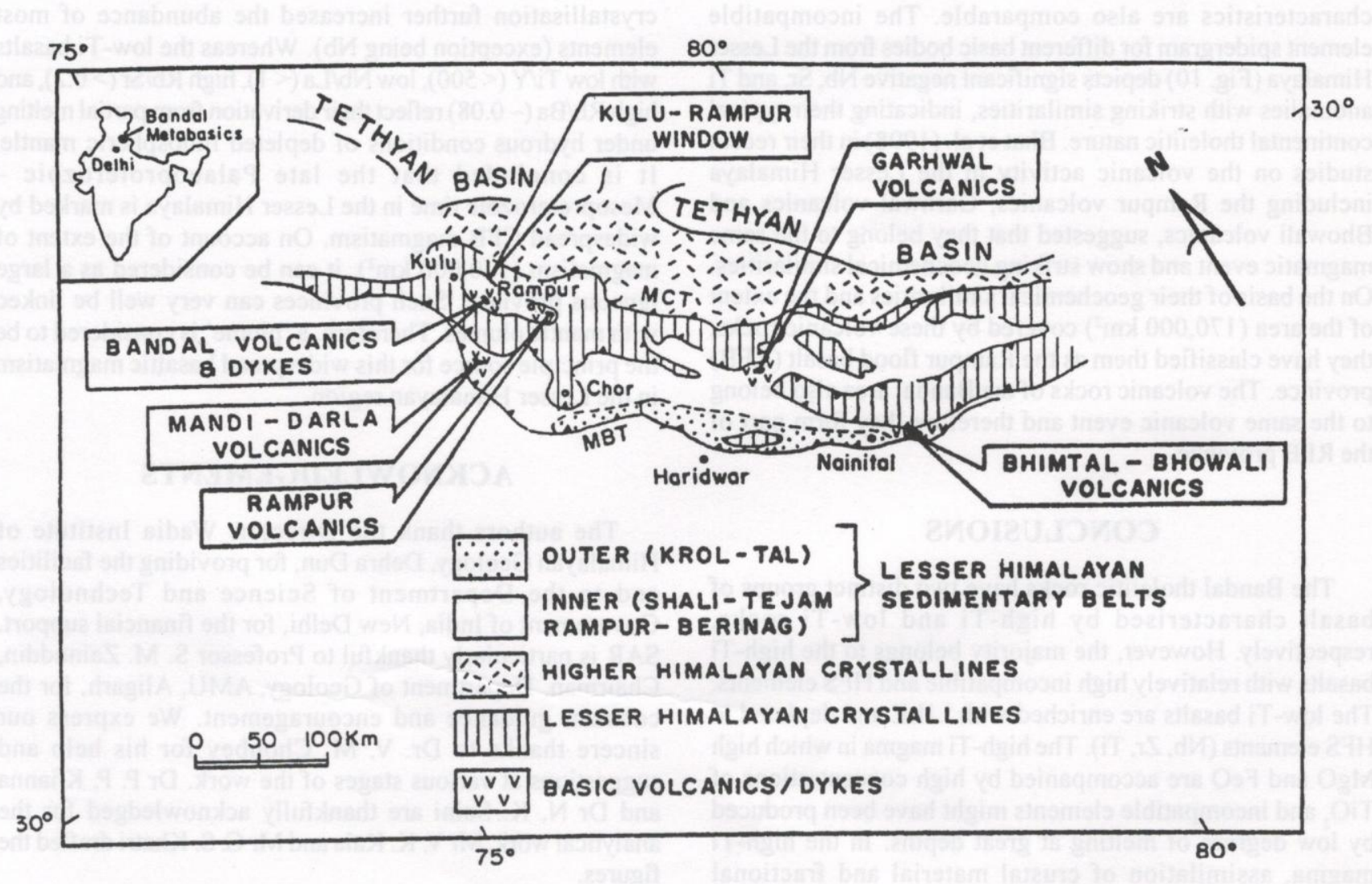

Fig. 9: Regional geological map showing the extent of basic magmatism in the Lesser Himalayan basin 


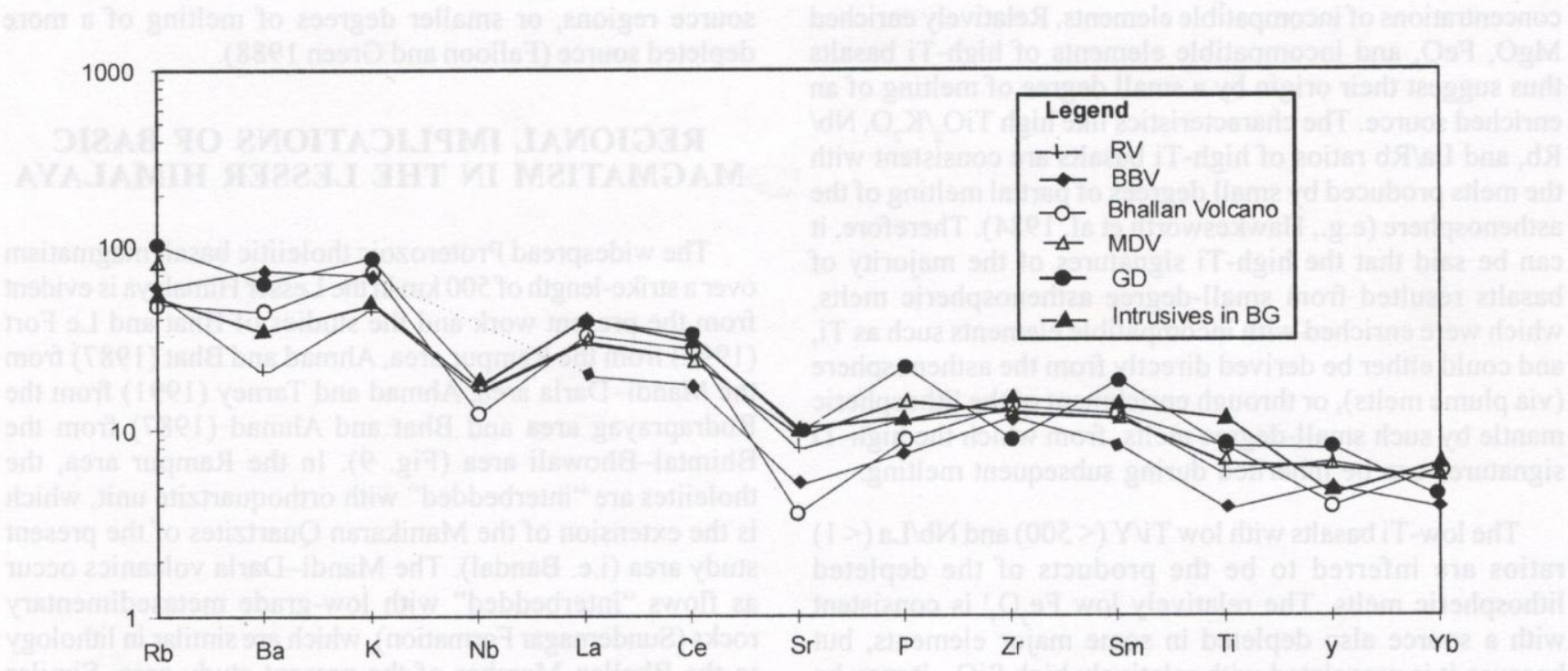

Fig. 10: PM-normalised multi-element spidergram showing comparison of the averages of Bandal basic rocks with different Proterozoic basic bodies from the Lesser Himalaya. MDV: Mandi-Darla volcanics (Ahmad and Bhat 1987), RV: Rampur volcanics (Bhat and Le Fort 1992), GD: Garhwal dykes and GV: Garhwal volcanics (Ahmad and Tarney 1991), BBV: Bhimtal-Bhowali volcanics (Bhat and Ahmad 1987). Normalising values after Sun and McDonough (1989)

characteristics are also comparable. The incompatible element spidergram for different basic bodies from the Lesser Himalaya (Fig. 10) depicts significant negative $\mathrm{Nb}, \mathrm{Sr}$, and $\mathrm{Ti}$ anomalies with striking similarities, indicating their typical continental tholeiitic nature. Bhat et al. (1998) in their recent studies on the volcanic activity in the Lesser Himalaya including the Rampur volcanics, Garhwal volcanics and Bhowali volcanics, suggested that they belong to the same magmatic event and show striking geochemical similarities. On the basis of their geochemical similarities and the extent of the area $\left(170,000 \mathrm{~km}^{2}\right)$ covered by these volcanic rocks, they have classified them as the Rampur flood basalt (RFB) province. The volcanic rocks of the Bandal area also belong to the same volcanic event and therefore they form part of the RFB province.

\section{CONCLUSIONS}

The Bandal tholeiitic rocks have two distinct groups of basalt characterised by high-Ti and low-Ti rocks, respectively. However, the majority belongs to the high-Ti basalts with relatively high incompatible and HFS elements. The low-Ti basalts are enriched with LILE and depleted in HFS elements ( $\mathrm{Nb}, \mathrm{Zr}, \mathrm{Ti})$. The high-Ti magma in which high $\mathrm{MgO}$ and $\mathrm{FeO}$ are accompanied by high concentrations of $\mathrm{TiO}_{2}$ and incompatible elements might have been produced by low degrees of melting at great depths. In the high-Ti magma, assimilation of crustal material and fractional crystallisation further increased the abundance of most elements (exception being $\mathrm{Nb}$ ). Whereas the low-Ti basalts with low $\mathrm{Ti} / \mathrm{Y}(<500)$, low $\mathrm{Nb} / \mathrm{La}(<1)$, high $\mathrm{Rb} / \mathrm{Sr}(>0.2)$, and high $\mathrm{Rb} / \mathrm{Ba}(\sim 0.08)$ reflect their derivation from partial melting under hydrous conditions of depleted lithospheric mantle. It is concluded that the late Palaeoproterozoic Mesoproterozoic time in the Lesser Himalaya is marked by widespread CFB magmatism. On account of the extent of magmatism $\left(170,000 \mathrm{~km}^{2}\right)$, it can be considered as a large igneous province. Such provinces can very well be linked with mantle plumes. Therefore, a 'plume' is considered to be the principle source for this widespread basaltic magmatism in the Lesser Himalayan region.

\section{ACKNOWLEDGEMENTS}

The authors thank the Director, Wadia Institute of Himalayan Geology, Dehra Dun, for providing the facilities and to the Department of Science and Technology, Government of India, New Delhi, for the financial support. SAR is particularly thankful to Professor S. M. Zainuddin, Chairman, Department of Geology, AMU, Aligarh, for the constant guidance and encouragement. We express our sincere thanks to Dr. V. M. Choubey for his help and suggestions at various stages of the work. Dr P. P. Khanna and Dr N. K. Saini are thankfully acknowledged for the analytical work. Mr V. K. Kala and Mr G. S. Khatri drafted the figures. 


\section{REFERENCES}

Ahmad, T. and Bhat, M. I., 1987, Geochemistry and petrogenesis of the Mandi-Darla volcanics, Northwestern Himalayas. Precamb. Res., v. 37, pp. 231-56.

Ahmad, T. and Tarney, J., 1991, Geochemistry and petrogenesis of Garhwal volcanics: implications for evolution of the north Indian lithosphere. Precamb. Res., v. 50, pp. 69-88.

Arndt, N. T. and Christensen, U., 1992, The role of lithospheric mantle in continental flood volcanism: Thermal and Geochemical constraints. Jour. Geophy. Res., v. 97, pp. 10967-10981.

Arndt, N. T., Czamanske, G. K., Wooden, J. L., and Fedorenko, V. A., 1993, Mantle and crustal contributions to continental flood volcanism. Tectonophysics, v. 223, pp. 39-52.

Bhat, M. I., 1987, Spasmodic rift-reactivation and its role in the pre-orogenic evolution of the Himalayas. Tectonophysics, v. 134, pp. 103-127.

Bhat, M. I. and Ahmad, T., 1987, Geochemistry and petrogenesis of the Bhowali-Bhimtal volcanics, Kumaun Lesser Himalaya. Geosci. Jour., v. 8, pp. 51-68.

Bhat, M. I. and Le Fort, P., 1992, Sm-Nd age and petrogenesis of Rampur metavolcanic rocks, NW Himalayas: Late Archaean relics in the Himalayan belt. Precamb. Res., v. 56, pp. 191-210.

Bhat, M. I., Claesson, S., Dubey, A. K., and Pandey, K., 1998, Sm-Nd ages of the Garhwal -Bhowali volcanics, Western Himalayas: vestiges of the late Archean Rampur flood basalts of the northern India craton. Precamb. Res., v. 87, pp. 217-231.

Bradshaw, T. K., Hawkesworth, C. J., and Gallagher, K., 1993, Basaltic volcanism in the Southern Basin and Range: no role for a mantle plume. Earth and Planet. Sci. Lett., v. 116, pp. $45-62$.

Campbell, I. H. and Griffiths, R. W., 1990, Implications of the mantle plume structure for the evolution of flood basalts. Earth and planet. Sci. Lett., v. 99, pp. 79-93.

Carlson, R. W., 1991, Physical and chemical evidence on the cause and source characteristics of flood basalt volcanism. Aust. Jour. Earth Sci., v. 38, pp. 525-544.

Clague, D. A. and Frey, F. A., 1982, Petrology and trace element geochemistry of the Honolulu volcanics, Oahu: implications for the oceanic mantle below Hawaii. Jour. Petrol., v. 23, pp. 447-504.

Cox, K. G., 1978, Flood basalts, subduction and the breakup of Gondwanaland. Nature, v. 274, pp. 47-49.

Duncan, R. A., 1978, Geochronology of basalts from the ninety east Ridge and continental dispersion in the eastern Indian Ocean. Jour. Volcano. Geotherm. Res. v. 4, pp. 283-305.

Duncan, R. A., Erlank, A. J., and Marsh, J. S., 1984, Regional geochemistry of the Karoo igneous province. Spec. Pub. Geol. Soc. South Afr., v. 13, pp. 355-388.

Ellam, R. M. and Cox, K. G., 1989, A Proterozoic lithospheric source for Karoo magmatism: Evidence from the Nuanetsi picrites. Earth Planet. Sci. Lett., v. 92, pp. 207-218.

Falloon, T. J. and Green, D. H., 1988, Anhydrous partial melting of peridotite from 8-35 kbar and the petrogenesis of MORB. Jour. Petrology, Spec. Lithosphere v., pp. 379-414.

Feigenson, M. D., Hofmann, A. W., and Spera, F. J., 1983, Case studies on the origin of basalt, II. The transition from tholeiitic to alkalic volcanism on Kohala volcano, Hawaii. Contrib. Mineral. Petrol., v. 84, pp. 390-405.
Frank, W., Thoni, M., and Purtscheller, F., 1977, Geology and petrography of Kullu-south Lahul area. In: Himalayas. Science de la Terre, CNRS., Paris, v. 268 , pp. 147-172.

Garland, F., Turner, S., and Hawkesworth, C., 1996, Shifts in the source of the Parana basalts through time. Lithos, v. 37, pp. 223-243.

Gallagher, K. and Hawkesworth, C. J., 1994, Mantle plumes, continental tectonics and asymmetry in the South Atlantic. Earth Planet. Sci. Lett., v. 123, pp. 105-118.

Hawkesworth, C. J., Rogers, N. W., Vancalsteren, and Menzies, M. A., 1984, Mantle enrichment process. Nature, v. 311, 331 p.

Hawkesworth, C. J., Mantovani, M., and Peate, D., 1988, Lithosphere remobilisation during Parana CFB magmatism. Jour. Petrol. (Sp. Issue), pp. 205-223.

Hergt, J. M., Peate, D. W., and Hawkesworth, C. J., 1991, The petrogenesis of Mesozoic Gondwana low-Ti flood basalts. Earth Planet. Sci. Lett. v. 105, pp. 134-148.

Jaques, A. L. and Green, D. H., 1980, Anhydrous melting of peridotite at $0-15 \mathrm{kbar}$ pressure and the genesis of tholeiitic basalts. Contrib. Mineral. Petrol., v. 73, pp. 287-310.

Le Bas, M. J., Le Maitre, R. W., Streckeisen, A. P., and Zanettin, B., 1986, A chemical classification of volcanic rocks based on the total alkali-silica diagram. Jour. Petrology, v. 27, pp. $745-750$.

Lightfoot, P. C. and Hawkesworth, C. J., 1988, Origin of Deccan Trap lavas: evidence from combined trace element and Sr-, $\mathrm{Nd}-$ and $\mathrm{Pb}$-isotope studies. Earth Planet. Sci. Lett. v. 91, pp. 89-104.

Mahoney, J., Macdougall, J. D., Lugmair, G. W., Murali, A. V., Sankar Das, M., and Gopalan, K., 1982, Origin of the Deccan trap flows at Mahabaleshwar inferred from $\mathrm{Nd}$ and $\mathrm{Sr}$ isotopic and chemical evidence. Earth Planet. Sci. Lett., v. 60, pp. $47-60$.

Mantovani, M. S. M., Marques, L. S., De Sousa, M. A., Civetta, L., Atalla, L., and Innocenti, F., 1985, Trace element and strontium isotope constraints on the origin and evolution of Parana continental flood basaits of Santa Catarina State (Southern Brazil). Jour. Petrol., v. 26, pp. 187-209.

McKenzie, D. P., 1989, Some remarks on the movement of small melt fractions in the mantle. Earth Planet. Sci. Lett., v. 95, pp. 53-72.

O'Hara, M. J., 1968, The bearing of phase equilibrium studies on the origin and evolution of basic and ultrabasic rocks. Earth Sci. Rev., v. 4, pp. 69-133.

Pearce, J. A., 1982, Trace element characteristics of lavas from destructive plate boundaries. In: Thorpe, R. S. (Ed.) Andesites, pp. 525-548.

Pharaoh, T. C. and Pearce, J. A., 1984, Geochemical evidence for the geotectonic setting of Early Proterozoic metavolcanic sequences in Lapland. Precamb. Res., v. 25, pp. 283-308.

Rajamani, V., Shirey, S. B., and Hanson, G. N., 1989, Fe-enriched Archean tholeiites derived from melt-enriched mantle source: evidence from the Kolar schist belt, south India. Jour. Geol., v. 97, pp. 487-501.

Rathi, M. S., Khanna, P. P., Mukherjee, P. K., and Saini., N. K., 1996, Evolution of REE determination in geological samples by Inductively Coupled Plasma Emission Spectrometry. Jour. Geol. Soc. India, v. 48, pp. 325-330.

Rossy, M., Azambre, B., and Albarede, F., 1992, REE and Sr-Nd isotopic geochemistry of the alkaline magmatism from the Cretaceous North Pyrenean Rift Zone (France-Spain). Chem. Geol., v. 97, pp. 33-46. 


\section{S. A. Rashid and Kewal K. Sharma}

Sharma, V. P., 1977, Geology of Kulu-Rampur belt, Himachal Pradesh. Geol. Surv. India Mem., No. 106(II), pp. 235-407.

Sun, S. -S. and McDonough, W. F., 1989, Chemical and isotopic systematics of oceanic basalts: implications for mantle composition and processes. In: A. D. Saunders and M. J. Norry (Eds.) Magmatism in oceanic basins. Geol. Soc. London Spec. Publ. No. 42, pp. 313-345.

Takahashi, E. and I. Kushiro., 1983, Melting of dry peridotite at high pressures and basalt magma genesis. Amer. Mineral., v. 68 , pp. $859-879$.

Tarney, J., Wood, D. A., Saunders, A. D., Varet, J., and Cann, J. R., 1979, Nature of mantle heterogeneity in the North Atlantic : evidence from Leg 49. In: Talwani, M. (Ed.) Results of Deep
Sea Drilling in the Atlantic. Maurice Ewing Series, 2. Amer. Geophy. Union, pp. 285-301.

Turner, S. and Hawkesworth, C., 1995, The nature of the continental mantle lithosphere: constraints from the major element composition of continental flood basalts. Chem. Geol., v. 120, pp. 295-314.

Vetter, S. K. and Shervais, J. W., 1992, Continental basalts of the Boise River Group near Smith Prairie, Idaho. Jour. Geophy. Res., v. 97, pp. 9043-9061.

White, R. and McKenzie, D., 1989, Magmatism at rift zones: the generation of volcanic continental margins and flood basalts. Jour. Geophy. Res., v. 94, pp. 7685-7729.

White, R. S. and McKenzie, D., 1995, Mantle plumes and flood basalts. Jour. Geophy. Res., v. 100, pp. 17543-17585. 